\title{
ZAPIS ANTONIEGO DYDYŃSKIEGO Z 2 LUTEGO 1808 ROKU - PRZYCZYNEK DO BADAŃ NAD FUNDACJĄ STYPENDIALNĄ IM. ANTONIEGO DYDYŃSKIEGO W GODOWEJ
}

\author{
Wojciech Ziobro \\ Uniwersytet Rzeszowski
}

\author{
ABSTRACT \\ ANTONI DYDYŃSKI'S BEQUEST OF FEBRUARY 2, 1808: \\ CONTRIBUTING TO THE RESEARCH ON THE ANTONI DYDYŃSKI \\ SCHOLARSHIP FOUNDATION IN GODOWA
}

This article is dedicated to the Antoni Dydyński Foundation in Godowa, one of the oldest and most prosperous scholarship foundations of the 19 th and the first half of the $20^{\text {th }}$ century. The Foundation's historical outline is presented by comparing the original idea expressed by the founder in the Foundation Act (from February 2, 1808) with the actual state after the foundation was established more than fifty years after its founder's death. The history of scholarships (up to a dozen each year), awarded without interruption by the foundation until 1939, is retraced on the basis of available sources. Finally, the foundation's scholars themselves are mentioned, as many of them, after receiving education in various centers from Cracow to Lviv, became prominent representatives of culture and science in Poland.

Keywords: Galicia, scholarship foundations, scientific patronage, scholarships.

Słowa kluczowe: Galicja, fundacje stypendialne, mecenat naukowy, stypendia.

Jednym z najbardziej rozwiniętych i efektywnych aspektów mecenatu naukowego XIX wieku w Galicji były fundacje stypendialne. W przededniu wybuchu I wojny światowej liczba fundacji zarządzanych tylko przez organy rządowe sięgnęła 566 czynnych (271 pod zarządem Namiestnictwa i 295 pod zarządem Wydziału 
Krajowego) i 46 niewprowadzonych jeszcze w życie. Obok tych fundacji funkcjonowało jeszcze kilkanaście zarządzanych przez Uniwersytet Jagielloński i Akademię Umiejętności ${ }^{1}$.

Do ważniejszych instytucji niosących pomoc pragnącej wykształcić się młodzieży, powstałych jeszcze w okresie przedautonomicznym, Julian Dybiec zalicza fundacje stypendialne utworzone przez: Samuela Rocha Głowińskiego (XVIII w.), Szczęsnego Łosia (1804), Adama Żebrowskiego (1806), Jędrzeja Żalchockiego (1845) i Jana Żurakowskiego (1859). Obok nich wymienia również fundację utworzoną w $1808 \mathrm{r}$. przez Antoniego Dydyńskiego z Godowej, której „,wysokie stypendia dla kilkunastu zazwyczaj uczniów corocznie zamykały się w granicach kilku tysięcy zł r. i z chwilą, gdy brakło kandydatów z oznaczonych statutowo rodzin, służyły dla kształcenia wielu wybitnych potem uczonych"'.

Krzysztof Ślusarek wymienia z kolei Fundację im. Antoniego Dydyńskiego obok dwu innych tego typu instytucji istniejących w pierwszej połowie XIX wieku (Fundacji Hallerów i Zakładu Narodowego im. Ossolińskich), których majątek w większości stanowiły dochody z dóbr ziemskich, a nie tylko aktywa ulokowane w papierach wartościowych, tak jak to było w przypadku większości zakładanych potem fundacji ${ }^{3}$. To właśnie dzięki temu Fundacja im. Antoniego Dydyńskiego w Godowej mogła przetrwać różnego rodzaju kryzysy i wojenne zawieruchy, przetaczające się przez ziemie polskie w XIX i XX wieku, i wspierać uczącą się młodzież aż do wybuchu wojny w 1939 roku.

Sama data urodzenia założyciela nie jest do końca znana, bowiem w herbarzach $\mathrm{i}$ innych dokumentach $\mathrm{z}$ tego okresu można natrafić na różne informacje. I tak na przykład w swoich Rodowodach Tadeusz Alojzy Jaszczurowski, powołując się na herbarz Kazimierza Łodzia Czarnieckiego, jako datę urodzenia Antoniego Dydyńskiego podaje rok 1729, podczas gdy inne źródła, w tym również późniejsze dokumenty rodzinne Dydyńskich i spokrewnionych z nimi Żuk-Skarszewskich, mówią o roku $1732^{4}$.

W pozostałych kwestiach dotyczących życia Antoniego Dydyńskiego wszystkie źródła są zgodne, jednoznacznie stwierdzając, że pełnił on urząd pilzneńskiego

1 Szematyzm Królestwa Galicyi i Lodomeryi z Wielkiem Księstwem Krakowskiem na rok 1914, Lwów 1914, s. 1278-1437; J. Dybiec, Mecenat naukowy i oświatowy w Galicji 1860-1918, Wrocław 1981, s. 53-54; G.P. Bąbiak, Sobie, ojczyźnie czy potomności... Wybrane problemy mecenatu kulturalnego elit na ziemiach polskich w XIX wieku, Warszawa 2010, s. 196.

2 J. Dybiec, Finansowanie nauki i oświaty w Galicji 1860-1918, Kraków 1979, s. 68.

3 K. Ślusarek, W przededniu autonomii. Własność ziemska i ziemiaństwo zachodniej Galicji w potowie XIX wieku, Warszawa 2013, s. 18, 34.

${ }^{4}$ K. Łodzia Czarniecki, Herbarz polski podtug Niesieckiego, treściwie ułożony i wypisami z późniejszych autorów, $z$ różnych akt grodzkich $i$ ziemskich, z ksiag $i$ akt kościelnych oraz z dokumentów familijnych powiększony $i$ wydany, t. 1, Gniezno 1875-1881, s. 449; Zakład Narodowy im. Ossolińskich we Wrocławiu (dalej: ZNiO), sygn. 15711/III, „Rodowody”. Tablice genealogiczne i materiały do nich dotyczące rodzin spokrewnionych z Jaszczurowskimi. Zebrał i zestawił Tadeusz Alojzy Jaszczurowski, Lit. Dy-J, poz. I. Dydyńscy v. Dedyńscy v. Didińscy h. Gozdawa: 1. Tablice genealogiczne, k. 49; ZNiO, akc. 200/82, Papiery rodzin Dydyńskich i Żuk-Skarszewskich: Tablice Genologiczne; Pamiętnik Mariana Dydyńskiego z Raciborska (1843-1920), wyd. K. Gołąb-Malowicka, Kraków 2015, Tabl. 6. Drzewo genealogiczne rodziny Dydyńskich, tablica VI (Zbiory Rodziny Morstinów). 
komornika granicznego (1788), a także piastował funkcję szambelana na dworze króla Stanisława Augusta Poniatowskiego (1784). W 1782 roku, wspólnie z braćmi Stanisławem Kostką i Franciszkiem, udowodnił zaś swoje szlacheckie pochodzenie przed sądem ziemskim w Sanokus.

Źródła zgodnie potwierdzają również fakt, że ożenił się z Konstancją, córką chorążego czerwonogrodzkiego Stanisława Rosnowskiego, ale nie pozostawił po sobie potomstwa. Jak można przeczytać w akcie fundacyjnym, to właśnie brak spadkobierców - zarówno po mieczu, jak i po kądzieli - oraz możliwości scedowania na nich swojego majątku był głównym powodem utworzenia fundacji na rzecz ubogiej młodzieży ${ }^{6}$.

W akcie fundacyjnym sporządzonym 2 lutego 1808 roku blisko osiemdziesięcioletni wówczas Antoni Dydyński przekazał część swojego majątku, a mianowicie całą majętność godowską, na utworzenie fundacji pomagającej w wykształceniu ubogiej młodzieży. Warto w tym miejscu dodać, iż zakupiona przez niego w 1784 roku za sumę 160000 złotych polskich od księcia Jerzego Lubomirskiego majętność (z prawem dziedziczenia), w skład której wchodziły: folwark i wieś Godowa, Żyznów Dolny, Piraczkówka i Przylaski, dzierżawiona była już wcześniej od Lubomirskich przez jego rodziców, Michała i Domicelę ze Stadnickich ${ }^{7}$.

W pierwotnym zamyśle Antoniego Dydyńskiego utworzona przez niego fundacja miała pomagać $\mathrm{w}$ wykształceniu czterech ubogich młodzieńców pochodzących z rodu Dydyńskich lub Rosnowskich przez zapewnienie im utrzymania w szkołach, między innymi zaopatrując $\mathrm{w}$ podstawowe środki do nauki, w tym potrzebną odzież i wyżywienie. W czasie wolnym od zajęć szkolnych miała im zaś zorganizować wypoczynek w dobrach fundacyjnych. W nowo wybudowanym przez fundatora pałacu w Godowej stypendyści mieliby dostęp do biblioteki, która - tak jak i sama fundacja - nosiłaby imię Antoniego Dydyńskiego i w której znajdować się miała aktualna literatura, co roku uzupełniana przez zarządcę fundacji o nowe pozycje ${ }^{8}$.

Stypendystów planowano wyłaniać w drodze konkursu, przy czym pierwszeństwo mieliby chłopcy w wieku od 7 do 15 lat, jak już wyżej wspomniano, wywodzący się $\mathrm{z}$ rodu fundatora. W przypadku ich braku wybierano by chłopców pochodzących z rodu

5 Poczet szlachty galicyjskiej i bukowińskiej, Lwów 1857, s. 58; A. Boniecki, Herbarz Polski, cz. 1: Wiadomości historyczno-genealogiczne o rodach szlacheckich, t. 5, Warszawa 1902, s. 135-136.

6 Lwowska Naukowa Biblioteka Ukrainy im. W. Stefanyka (dalej: LBN), zesp. (fond) 141, Zbiór Aleksandra Czołowskiego, dział (opis) II, sygn. 161, Papiery rodzinno-majątkowe Franciszka Dydyńskiego (1698-1836), k. 100-101, Odpis aktu ustanowienia Fundacji Stypendialnej przez Antoniego Dydyńskiego (2 II 1808).

7 Zachowały się trzy kontrakty dzierżawy z lat 1755-1758, 1764-1767 i 1771-1774. ZNiO, sygn. 12329/II, Księga spraw majątkowych księżny Joanny de Stein Lubomirskiej, chorążyny wielkiej koronnej z lat 1755-1761, poz. 10, Copia kontraktu z WJM panem Michałem Dydyńskim, chorążym zakroczymskim, o dobra godowskie. Anno 1755, s. 63-66, poz. 41, Copia kwitu na z. 700 vigore prorogacyi kontraktu z dóbr godowskich od WW Jchm PP Dydyńskich pro die 24 Marc 1760 Anno należących y odebranych, s. 350; Archiwum Państwowe w Rzeszowie (dalej: APRz), zesp. 519, Archiwum Lubomirskich, sygn. 22, Kontrakty dzierżawy wsi i miast $(1665,1771)$, k. 8-15; LBN, zesp. 141, dział II, sygn. 161, k. 71-72, Kopia kontraktu kupna i sprzedaży dóbr wsi Godowy z jej przyległościami, zawartego między JXW Jerzym Lubomirskim a Antonim z Dydni Dydyńskim (7 VI 1784).

8 LBN, zesp. 141, dział II, sygn. 161, k. 100-101, Odpis aktu ustanowienia Fundacji Stypendialnej przez Antoniego Dydyńskiego (2 II 1808). 
Rosnowskich. Gdyby i takich zabrakło, pomoc przypadałaby młodzieńcom wywodzącym się z innych rodów szlacheckich, a jedynym warunkiem było ich ex legitymo matrimonia nata. Po otrzymaniu uposażenia stypendyści w każdym roku szkolnym musieliby wykazywać się obyczajnością i postępami w nauce, w przeciwnym wypadku mogli zostać pozbawieni uposażenia, a ich miejsce przypaść miało zasługującym na to uczniom. Stypendysta, który spełniał wszystkie kryteria, mógł otrzymywać pomoc aż do usamodzielnienia się i podjęcia pracy zarobkowej'.

Nad powołaniem do życia fundacji i późniejszą jej działalnością miał czuwać zarządca. Jako pierwszy na to stanowisko mianowany został przez Antoniego Dydyńskiego Rafał Niedźwiecki h. Ostoja. To on miał przygotować majątek pod działalność fundacji, a także zadecydować o jej uruchomieniu i wydawaniu pierwszych uposażeń dla uczniów. Zakładano, że po nim, również w drodze konkursu, będą wybierani następni, ale i w tym przypadku pierwszeństwo przypadać miało osobom pochodzącym z rodu Dydyńskich. Za swoją pracę zarządca otrzymywałby darmowe mieszkanie w godowskim dworze i drewno na opał z lasu należącego do fundacji, a także pobierałby roczną pensję w wysokości 8000 florenów $^{10}$.

Rzeczywistość wyglądała jednak zupełnie inaczej. Ani wyznaczonemu w akcie pierwszemu zarządcy, ani kolejnemu, którym został Antoni Dydyński z Sieklówki ${ }^{11}$, nie udało się wcielić w życie ostatniej woli fundatora, przez co, jak pisze autor Rozprawy o funduszach krajowych, fundacja pozostawała zaniedbana przez ponad 50 lat $^{12}$.

W Sprawozdaniu Wydziału Krajowego z 1861 roku można przeczytać, że jeszcze w roku 1825 niezrealizowanym zapisem Fundacji im. Antoniego Dydyńskiego z Godowej zainteresował się Wydział Stanowy, ale nie poczyniono żadnych kroków, aby urzeczywistnić ostatnią wolę jej fundatora ${ }^{13}$.

Sprawa ponownie ujrzała światło dzienne dopiero w 1861 roku, kiedy to zainteresowało się nią Namiestnictwo. Wezwało ono Wydział Stanowy do ostatecznego uregulowania wszystkich kwestii dotyczących niezrealizowanego dotąd zapisu. Jeszcze w tym samym roku powołano kuratora dla fundacji, którego zadaniem było uporządkowanie jej majątku i poczynienie odpowiednich kroków w celu urzeczywistnienia woli fundatora ${ }^{14}$. Kuratorem tym został Ignacy Skrzyński ze Strzyżowa ${ }^{15}$.

9 Ibidem.

10 Ibidem.

11 Antoni Dydyński (1794-1879), syn Franciszka i Tekli z Sędzimirów, ożeniony z Karoliną z Mięta-Mikołajewiczów (1810-1829), a następnie z Teresą (1820-1846), córką Michała Marcina Klemensa Dydyńskiego i Rozalii z Jarosiewiczów, a wnuczką Stanisława Kostki Dydyńskiego - brata Antoniego Dydyńskiego. Właściciel Sieklówki w powiecie jasielskim. Od ok. 1820 r. do 1861 r. administrator Fundacji im. Antoniego Dydyńskiego.

12 Rozprawa o funduszach krajowych, Lwów 1865, s. 128-129.

13 Archiwum Narodowe w Krakowie (dalej: ANKr), zesp. 684, Teki Antoniego Schneidra, sygn. 62, s. 553.

14 Ibidem.

15 Ignacy Skrzyński h. Zaremba (1807-1895), syn Wincentego i Konstancji z Fredrów, ożeniony z Marią ze Skrzyńskich, oficer wojsk polskich w 1831 r., a także poseł do parlamentu austriackiego w 1848 r. i Sejmu Krajowego Galicji I kadencji. Był właścicielem dominium Strzyżów, w skład którego wchodziły miasteczko Strzyżów i sześć wsi (Brzeżanka, Gbiska, Grodzisko, Łętownia, Przedmieście 
Nowo mianowany kurator od razu przystąpił do realizacji powierzonego mu zadania i już w kolejnym roku prasa donosiła o uruchomieniu fundacji, która przeorganizowana na stypendialną jeszcze w roku szkolnym 1861/1862 przyznała pierwsze cztery stypendia w wysokości 300 złotych reńskich każde. Pierwszymi zaś stypendystami Fundacji im. Antoniego Dydyńskiego w Godowej zostali uczniowie: Marian i Aleksander Dydyńscy ze Lwowa, Szczepan Dydyński z Limanowej i Leon Dydyński z Drohobycza ${ }^{16}$.

Przemianowanie Fundacji im. Antoniego Dydyńskiego na stypendialną nie było jedyną zmianą, jaka zaszła w stosunku do pierwotnego zamysłu fundatora. Zainteresowane nią w dalszym ciągu władze postanowiły wziąć instytucję pod swoją opiekę. Mimo że w akcie fundacyjnym jego autor nic nie wspominał o tym, w jakim stopniu organy te mogą na nią wpływać, to do roku 1872 zarządem i opieką nad fundacją, a także przyznawaniem stypendiów przy pomocy powołanego kuratora zajmowało się Namiestnictwo, zaś po roku 1872 - Wydział Krajowy we Lwowie. Po odzyskaniu niepodległości opiekę nad organizacjami tego typu sprawował Tymczasowy Wydział Samorządowy we Lwowie, a następnie wojewoda lwowski przy pomocy departamentu fundacyjnego ${ }^{17}$.

Poznane dotychczas źródła wymieniają czterech kuratorów Fundacji im. Antoniego Dydyńskiego. Pierwszym z nich był wspominany już Ignacy Skrzyński, który sprawował tę funkcję aż do roku 1884, kiedy to z powodu podeszłego wieku i złego stanu zdrowia sam poprosił Wydział Krajowy o zwolnienie go z kurateli. Na stanowisku zastąpił go jego zięć Hipolit Wołkowicki ${ }^{18}$, po którym do 1922 roku kuratorem był Zdzisław Skrzyński ${ }^{19}$, syn Ignacego Skrzyńskiego. Po jego rezygnacji, od 1923 roku, ostatnim znanym kuratorem fundacji został Emil Niewolkiewicz (18801966), dyrektor lasów biskupstwa przemyskiego ${ }^{20}$.

Strzyżowskie i Tropie). Ponadto w posiadaniu Ignacego Skrzyńskiego znajdowały się jeszcze dobra Harta z Lipnikiem i Paprociem oraz wieś Glinik Charzewski i część Godowej zwana „Szpitalną”. Kurator Fundacji im. Antoniego Dydyńskiego w 1. 1861-1884.

16 „Czas” 1862, nr 138.

17 Szematyzm... [za lata 1861-1914], Lwów 1861-1914; M. Małecki, Wydział krajowy sejmu galicyjskiego. Geneza, struktura i zakres kompetencji, następstwo prawne, Kraków 2014, s. 407-418.

18 Hipolit Wołkowicki h. Lubicz, mąż Konstancji, córki Ignacego Skrzyńskiego (1807-1895), kurator Fundacji im. Antoniego Dydyńskiego w 1. 1884-1889.

19 Zdzisław Skrzyński h. Zaremba (1846-1927), syn Ignacego i Marii ze Skrzyńskich, poseł do Sejmu Krajowego Galicji IV, VI, VII, VIII i IX kadencji. Właściciel dóbr ziemskich: Bachórz z Chodorkówką, Harty z Lipnikiem i Paprociem, Błażowej Dolnej i Górnej ze Stanikiem i Wolą Błażowską, a także okolicznych wsi: Białki z Wulką, Futomy, Kąkolówki z Głęboką, Nowej Wsi oraz Piątkowej z Wolą. Członek C.K. Galicyjskiego Towarzystwa Gospodarskiego we Lwowie. Wieloletni członek rady powiatu w Brzozowie, a od 1913 r. jej prezes. Kurator Fundacji im. Antoniego Dydyńskiego w 1. 1890-1922.

20 Sprawozdanie z czynności Wydziału Krajowego za czas od 1 lipca 1884 do końca czerwca 1885 roku z alegatami 1-52 i indeksem [w:] Alegata do sprawozdań stenograficznych z trzeciej sesyi piatego perydu Sejmu Krajowego Królestwa Galicyi i Lodomeryi wraz z Wielkiem Ks. Krakowskiem z roku 1885/6, s. 140; Sprawozdanie z czynności Tymczasowego Wydziału Samorządowego we Lwowie za czas od 20 czerwca 1920 r. do 31 grudnia 1922, Lwów 1924, s. 72; Sprawozdanie z czynności Tymczasowego Wydziału Samorządowego we Lwowie za czas od 1 stycznia 1923 r. do 31 grudnia 1924 r., Lwów 1926, s. 136. 
Władze postanowiły poczynić również zmiany w innym punkcie statutu pierwotnie zaproponowanego przez fundatora. Mianowicie postanowiono odstąpić od organizowania wypoczynku dla stypendystów w dobrach należących do fundacji, a co za tym idzie - nie przeznaczać żadnych środków na mającą się mieścić w pałacu godowskim bibliotekę. W zamian za to postanowiono wydzierżawić cały majątek, a uzyskany w ten sposób dochód przeznaczyć na stypendia ${ }^{21}$. Do pomysłu organizacji wypoczynku w dobrach fundacyjnych powrócono dopiero w 1926 roku, kiedy to zorganizowano dwie pierwsze kolonie wypoczynkowe dla 30 ubogich uczniów, wśród których 16 było wychowankami bursy Towarzystwa Szkół Ludowych w Tarnopolu, a 14 pochodziło ze szkół Górnego Śląska. Również wtedy odstąpiono jednak od pierwotnej intencji Antoniego Dydyńskiego, ponieważ żaden z wypoczywających w dobrach fundacyjnych uczniów nie był jej stypendystą ani tym bardziej nie pochodził z rodu fundatora czy też jego żony ${ }^{22}$.

Wydzierżawienie majątku fundacyjnego stało się możliwe między innymi za sprawą drugiego administratora fundacji, Antoniego Dydyńskiego, który przez cały okres zarządzania nim, jak pisał w swoim Pamiętniku Marian Dydyński: „nieodpowiednio pojmując swoje zadanie, więcej niż zasadniczym celem fundacji zajmował się podniesieniem Godowy, głównie przez stawianie kosztownych budynków gospodarczych"²3. Nawiasem mówiąc, inwestycje te doprowadziły Antoniego Dydyńskiego na skraj bankructwa, gdyż w wielu przypadkach musiał on dokładać pieniądze z prywatnej kasy. W końcu zmiany dosięgły też i jego. Niedługo po przejęciu przez rząd opieki nad fundacją został pozbawiony funkcji jej administratora. Zarzucono mu niewywiązywanie się z głównego celu, jaki postawił przed pierwszymi administratorami założyciel fundacji ${ }^{24}$.

Zaopatrzony w nowe zabudowania dworskie i folwarczne majątek fundacyjny, nim jeszcze został puszczony w dzierżawę, podzielono na dwie sekcje, a każda z nich stanowiła przedmiot osobnej arendy. Pierwszą sekcją był folwark Godowa, do którego, obok zabudowań dworskich, należało jeszcze ponad 180 hektarów pól ornych, 25 hektarów pastwisk, 20 hektarów łąk i ponad hektar ogrodów. W skład drugiej sekcji wchodziły zaś folwark „Skała” i Piraczkówka ze 102 hektarami pól ornych, 12 hektarami łąk i blisko 10 hektarami pastwisk. $Z$ czasem z drugiej sekcji wydzielony i puszczony w osobną dzierżawę został folwark Piraczkówka (ok. 35 ha) ${ }^{25}$. Ponadto

21 Ibidem.

22 Sprawozdanie z czynności Tymczasowego Wydziatu Samorzadowego we Lwowie za rok 1926, Lwów 1927, s. 213.

23 Pamiętnik Mariana Dydyńskiego..., s. 30.

24 Ibidem, s. 29.

25 Archiwum Państwowe w Przemyślu (dalej: APPr), gr. zesp. Akta notariuszy miasta Strzyżowa z lat 1873-1947, zesp. 1246, Akta c.k. notariusza Feliksa Miskyego w Strzyżowie, sygn. 5, nr 675, Kontrakt dzierżawy dóbr Godowa sekcji I należących do fundacji stypendialnej śp. Antoniego Dydyńskiego, zawarty pomiędzy, działającym w imieniu fundacji, Janem Stanisławem Ignacym Skrzyńskim właścicielem dóbr Strzyżowa z przyległościami i kuratorem tejże fundacji, a Adolfem Kernem dotychczasowym dzierżawcą folwarku Godowy sekcji I (30 V 1881); APPr, gr. zesp. Akta notariuszy miasta Strzyżowa z lat 1873-1947, zesp. 1246, sygn. 5, nr 676, Kontrakt dzierżawy dóbr Godowa sekcji II należących do fundacji stypendialnej śp. Antoniego Dydyńskiego, zawarty pomiędzy, działającym w imieniu fundacji, Janem Stanisławem Ignacym Skrzyńskim 
dochód dostarczały również eksploatacja ponad 570 hektarów lasu i wynajmowanie pomieszczeń w należącym do Fundacji budynku w Strzyżowie ${ }^{26}$.

Planowano, że opiekę nad majątkiem fundacji będzie sprawował powołany w tym celu administrator, który pod kierownictwem i nadzorem kuratora, jak czytamy w ogłoszeniu konkursowym, miał: ,,prowadzić zwykły zarząd rzeczonego majątku, czuwać nad całością onego, względem dóbr Godowy wykonywać wszelkie obowiązki przełożonego obszaru dworskiego i w ogóle starać się o dobro i pomyślność majątku powierzonego swej administracji”' ${ }^{27}$. Za pracę administrator otrzymywać miał roczne wynagrodzenie w wysokości 800 złotych, bezpłatne mieszkanie w specjalnie na ten cel zakupionym przez fundację budynku w Strzyżowie i ryczałt na prowadzenie kancelarii w wysokości 20 złotych rocznie, a w razie koniecznej potrzeby mógłby dostać dodatkowe środki pieniężne ${ }^{28}$.

Jak już wyżej wspomniano, zgodnie z wolą fundatora administratora powoływano w drodze konkursu, który od 1872 roku ogłaszany był przez Wydział Krajowy. Zgłosić się do niego mógł każdy, kto uznał, że jest w stanie w odpowiedni sposób zarządzać takim majątkiem. Z szacunku dla woli fundatora pierwszeństwo w konkursie przyznawano jednak członkom jego rodu, o ile oczywiście dorównywali oni pozostałym kandydatom ${ }^{29}$.

W przeciągu ponadosiemdziesięcioletniej działalności Fundacji im. Antoniego Dydyńskiego konkurs na stanowisko administratora ogłaszano czterokrotnie ${ }^{30}$. I tak w 1873 roku na trzeciego administratora wybrany został Nikodem Dydyński, pełniący dotychczas obowiązki prowizorycznego zarządcy dóbr fundacji po odwołaniu w 1861 roku Antoniego Dydyńskiego ${ }^{31}$. Po śmierci Nikodema Dydyńskiego w 1874 roku, do czasu wyłonienia nowego zarządcy, administrację przejściową sprawował Józef Etgens $^{32}$. W 1875 roku musiał on ustąpić miejsca nowo wybranemu Apolinaremu

właścicielem dóbr Strzyżowa z przyległościami i kuratorem tejże fundacji, a Karolem Krasińskim dotychczasowym dzierżawcą folwarku Godowy sekcji II (30 V1881); APPr, gr. zesp. Akta notariuszy miasta Strzyżowa z lat 1873-1947, zesp. 1248, Notariusz Adam Bański w Strzyżowie, sygn. 18, nr 3521, Kontrakt dzierżawy folwarku Godowa zawarty z Stanisławem Filipowiczem (2 X 1929).

26 APPr, gr. zesp. Akta notariuszy miasta Strzyżowa z lat 1873-1947, zesp. 1246, sygn. 3, nr 502, Legalizacja podpisu na kontrakcie najmu z dnia 30 X 1880 r., mocą którego Apolinary Dydyński działając w imieniu dóbr funduszowych Godowa, wypuszcza w najem Towarzystwu Zaliczkowemu i Kredytowemu w Strzyżowie pomieszczenia w budynku z realności w Strzyżowie położonej i do fundacji tej należącej (2 XI 1880).

27 „Gazeta Lwowska” 1873, nr 66-69.

28 Ibidem.

29 Ibidem.

30 „Gazeta Lwowska” 1875, nr 49-51; 1881, nr 102-103, 106; Sprawozdanie... za czas od 20 czerwca 1920 r. do 31 grudnia 1922 r., s. 72; Sprawozdanie... za czas od 1 stycznia 1923 r. do 31 grudnia 1924 r., s. 136.

31 Nikodem Michał Marceli Dydyński (1816-1874), syn Piotra i Marianny z Goszałowiczów, ożeniony Antoniną, córką Antoniego Podoleckiego. Jeden z współtwórców, a następnie wicedyrektor Towarzystwa Zaliczkowego i Kredytowego w Strzyżowie. Administrator Fundacji im. Antoniego Dydyńskiego w 1. 1873-1874.

32 APPr, gr. zesp. Akta notariuszy miasta Strzyżowa z lat 1873-1947, zesp. 102, C.K. notariusz Konstanty Rogalski w Strzyżowie, sygn. 2, nr 319, Protokół odbioru przez Józefa Etgensa akt urzędowych dotyczących fundacji edukacyjnej śp. Antoniego Dydyńskiego (31 XII 1874). 
Dydyńskiemu z Grąziowy ${ }^{33}$. Gdy zaś ten zmarł w 1881 roku, stanowisko otrzymał jego syn Stanisław Dydyński, który zarządzał majątkiem fundacji najdłużej, bo przez blisko 41 lat $^{34}$. Ponadto w latach 1916-1921 dzierżawił on również majątek fundacji.

W 1922 roku zarządzający fundacjami stypendialnymi Tymczasowy Wydział Samorządowy we Lwowie postanowił odwołać Stanisława Dydyńskiego ze stanowiska, ponieważ ten większość swojego czasu spędzał w Krakowie, gdzie poświęcał się pracy na rzecz Towarzystwa Wzajemnych Ubezpieczeń, którego od 1911 roku był jednym z dyrektorów. Zaniedbywany przez niego majątek fundacyjny zaczął podupadać, przez co spadły dochody $\mathrm{z}$ niego otrzymywane ${ }^{35}$. Jednocześnie $\mathrm{w}$ wytoczonym procesie sądowym zarzucano Stanisławowi Dydyńskiemu działania na szkodę fundacji przez bezprawne poddzierżawianie jej majątku bez wiedzy i zezwolenia Wydziału Krajowego, a także wydzierżawienie sobie po zaniżonej cenie gruntów należących do fundacjii ${ }^{36}$.

Do czasu wyłonienia nowego administratora, w miejsce Stanisława Dydyńskiego Tymczasowy Wydział Samorządowy powołał jako prowizorycznego zarządcę dóbr i lasów fundacyjnych Bronisława Borysa. Po rozstrzygnięciu zaś konkursu w 1923 roku szóstym i zarazem ostatnim administratorem i leśniczym w dobrach Fundacji im. Antoniego Dydyńskiego w Godowej został Zdzisław Gieruszyński. Bronisława Borysa mianowano zaś leśniczym w dobrach Fundacji im. Wiktora hr. Baworowskiego mieszczących się na terenach ówczesnych powiatów tarnopolskiego i trembowelskiego ${ }^{37}$.

Taki stan rzeczy w Fundacji im. Antoniego Dydyńskiego utrzymał się aż do wybuchu II wojny światowej. Po zajęciu tych terenów przez armię niemiecką i włączeniu ich w skład Generalnego Gubernatorstwa administracja okupacyjna zlikwidowała wszystkie fundacje i stowarzyszenia, zajmując posiadany przez nie majątek ${ }^{38}$. Nawet po wyzwoleniu ziem polskich przez Armię Czerwoną w 1944 roku instytucji nie było

33 Apolinary Piotr Innocenty Dydyński (1819-1881), syn Michała Marcina Klemensa i Rozalii z Jarosiewiczów, ożeniony z Sybillą z Pieściorowskich, córką Marcina i Józefy z Nowosieleckich. Administrator Fundacji im. Antoniego Dydyńskiego w 1. 1875-1881.

34 Stanisław Kostka Mikołaj Dydyński (1855-1927), syn Apolinarego i Sybilli z Pieściorowskich, ożeniony z Anną z Żuk-Skarszewskich, córką Adama i Aleksandry z Bzowskich. Wieloletni członek rady powiatowej w Rzeszowie, a także członek i jeden z dyrektorów Towarzystwa Wzajemnych Ubezpieczeń w Krakowie. Kurator Fundacji im. Ryszarda Pieściorowskiego, a w 1. 1881-1922 administrator Fundacji im. Antoniego Dydyńskiego.

35 Sprawozdanie... za czas od 1 stycznia 1923 r. do 31 grudnia 1924 r., s. 136.

36 Ibidem; APPr, zesp. 65, Sąd Powiatowy w Strzyżowie, sygn. 72(132)/2005, Fundacja Stypendialna śp. Antoniego Dydyńskiego przeciw Stanisławowi Dydyńskiemu i wspólnikom o oddanie przedmiotu dzierżawy (1921-1923), 121 ss. W tym samym czasie sprawy dotyczące nielegalnego poddzierżawiania gruntów toczyły się także przeciwko innym dzierżawcom: APPr, zesp. 65, Sąd Powiatowy w Strzyżowie, sygn. 89(132)/2005, Fundacja Stypendialna im. Antoniego Dydyńskiego przeciw Jakubowi Szczygłowi o ustąpienie z posiadania (1928 [1929]), 23 ss.; APPr, zesp. 65, Sąd Powiatowy w Strzyżowie, sygn. 120(132)/2005, Fundacja Stypendialna im. Antoniego Dydyńskiego przeciw Janowi Zamorskiemu o naruszanie w posiadaniu gruntu (1928 [1929]), 24 ss.; APPr, zesp. 65, Sąd Powiatowy w Strzyżowie, sygn. 90(132)/2005, Fundacja Stypendialna im. Antoniego Dydyńskiego przeciw Stanisławowi Moskalowi o ustąpienie z posiadania (1926-1928 [1929]), 43 ss.

37 Sprawozdanie... za czas od 1 stycznia 1923 r. do 31 grudnia 1924 r., s. 136.

38 Działalność władz okupacyjnych na terytorium Rzeczypospolitej w okresie 1 IX 1939-1 XI 1940. Raport z archiwum politycznego prof. Stanisława Kota, wstęp, wybór i oprac. J. Gmitruk, J. Mazurek, Warszawa 1999, s. 231-234. 
dane wznowić działalności, gdyż działający na wyzwalanym obszarze PKWN wydał 6 września 1944 roku dekret o reformie rolnej, na mocy którego mający przeszło 300 hektarów majątek ziemski fundacji uległ parcelacji, a las i zabudowania dworskie przeszły na własność państwa. Ziemię otrzymało 279 osób, zaś inwentarz żywy i martwy rozparcelowano pomiędzy 47 osób. Ponadto 4 hektary ziemi fundacyjnej przeznaczono jeszcze dla szkoły rolniczej, a 2,4 hektara dostała szkoła powszechna ${ }^{39}$. W ten sposób zakończyła działalność jedna z najstarszych XIX-wiecznych fundacji stypendialnych.

Nie wypada nie wspomnieć również w kilku zdaniach o głównym celu Fundacji im. Antoniego Dydyńskiego z Godowej, jakim było niesienie pomocy kształcącej się ubogiej młodzieży, oraz o samych jej stypendystach.

Po powołaniu do życia fundacji i przemianowaniu jej na stypendialną przez cały okres działalności przyznawała ona od kilku do kilkunastu stypendiów rocznie. Niemal w każdym roczniku „Gazety Lwowskiej” znaleźć można informacje o konkursie, którego celem było nadanie dwóch lub trzech stypendiów z Fundacji im. Antoniego Dydyńskiego ${ }^{40}$.

Z informacji zamieszczonych w Szematyzmach wynika, że w latach 1861-1914 fundacja nadała 487 stypendiów, z czego 35, gdy zarządzało nią Namiestnictwo, a pozostałe 452 pod zarządem Wydziału Krajowego ${ }^{41}$. Dane te nie znajdują jednak odzwierciedlenia w Sprawozdaniach Wydziału Krajowego, w których liczby przyznanych przez Fundację im. Antoniego Dydyńskiego stypendiów nieco różnią się od tych podawanych w Szematyzmach. I tak, kiedy w Sprawozdaniach przeczytać można, że w roku 1875 wydano 9 stypendiów, w 1877 - 7, w 1879 - 6, w 1880 - 9, w 1881 - 9, w 1883 - 9, w 1884 - 10, w 1885 - 10, w 1886 - 13, a w roku 1887 - 10, to w Szematyzmach podano, że w latach $1875,1877,1879-1881$ i 1883-1886 wydano po 9 stypendiów rocznie, a w 1887 roku ich liczba sięgnęła $13^{42}$.

39 APRz, zesp. 308, Powiatowy Pełnomocnik dla spraw Reformy Rolnej w Rzeszowie, sygn. 37, Administracja przejściowa majątku w Godowej. Sprawozdania i korespondencja (1944), k. 5; APRz, zesp. 152, Wojewódzki Urząd Ziemski w Rzeszowie, sygn. 824, Parcelacja majątków: Mrowla, Słocina, Chmielnik, Kosina, Werynia, Kolbuszowa, Załęże, Rogóżno, Wola Mała, Łańcut, Łańcut „Górne”, Błażowa, Godowa (1944), k. 448-449, 746-763; T. Bieda, Pierwsze lata niepodległości w regionie strzyżowskim 1944-1947 [w:] Studia nad dziejami Strzyżowa i okolic, red. S. Cynarski, Rzeszów 1980, s. 302-303.

40 „Gazeta Lwowska” 1861-1914.

41 Szematyzm... [za lata 1861-1914].

42 Ibidem; Sprawozdanie Wydziału Krajowego o zamknięciu rachunków funduszów krajowych za rok 1875, Lit. C, Zamknięcie rachunku funduszów samoistnych (niedotowanych) budżetem nieobjętych za rok 1875 [w:] Alegata do sprawozdań stenograficznych z pierwszej sesyi czwartego perydu Sejmu Krajowego Królestwa Galicyi i Lodomeryi wraz z Wielkiem Ks. Krakowskiem z roku 1877, s. 163; Sprawozdanie Wydziału Krajowego o zamknięciu rachunków funduszów krajowych za rok 1877, Lit. B, Zamknięcie rachunku funduszów samoistnych (niedotowanych) budżetem nieobjętych za rok 1875 [w:] Alegata do sprawozdań stenograficznych z trzeciej sesyi czwartego perydu Sejmu Krajowego Królestwa Galicyi i Lodomeryi wraz z Wielkiem Ks. Krakowskiem z roku 1880, s. 26; Sprawozdanie Wydziału Krajowego o zamknięciu rachunków funduszów krajowych za rok 1879, Lit. B, Zamknięcie rachunku funduszów samoistnych (niedotowanych) budżetem nieobjętych za rok 1879 [w:] Alegata do sprawozdań stenograficznych z czwartej sesyi czwartego perydu Sejmu Krajowego Królestwa Galicyi i Lodomeryi wraz z Wielkiem Ks. Krakowskiem z roku 1881, s. 24; Sprawozdanie Wydziatu Krajowego o zamknięciu rachunków funduszów krajowych za 
Niestety na podstawie samych Sprawozdań nie można również ustalić dokładnej liczby przyznanych stypendiów, ponieważ dane dotyczące ich liczby ani imienne wykazy stypendystów nie były umieszczane w każdym ze sprawozdań, ale tylko przez pewien okres. Dlatego też dokładne dane co do ilości wydawanych przez fundację stypendiów i ich kwot ustalić można jedynie dla roczników: 1875, 1877, 1879-1881 i 1883-1887. Na załączonych listach imiennych stypendystów widnieją zaś takie znane później nazwiska, jak Władysław Leopold Jaworski (1865-1930) - profesor prawa UJ; Piotr Bieńkowski (1865-1925) - profesor archeologii UJ; Ignacy Zakrzewski (1860-1932) - profesor fizyki Uniwersytetu Lwowskiego; Stefan Ramułt (18591913) - językoznawca ${ }^{43}$.

W latach 1861-1878 kwoty wypłacanych przez Fundację im. Antoniego Dydyńskiego z Godowej subsydiów utrzymywały się na jednakowym poziomie 300 złotych reńskich rocznie dla każdego z jej stypendystów i były wypłacane w dwóch równych ratach. W 1878 roku dysponujący majątkiem Fundacji Wydział Krajowy postanowił, że wysokość wypłacanego wsparcia finansowego zależała będzie od tego, na jakim poziomie kształcenia znajduje się podopieczny fundacji. I tak, stypendyści uczący się w szkołach ludowych otrzymywać mieli po 240 złotych reńskich, uczący się w szkołach średnich - 300, a kształcący się na uczelniach wyższych - po 360 rocznie. Podtrzymano ratalny system wypłacania stypendiów. Utrzymał się on aż do 1939 roku. Dzięki rosnącym wpływom z majątku fundacyjnego od roku szkolnego 1893/1894

rok 1880, Lit. B, Zamknięcie rachunku funduszów samoistnych (niedotowanych) budżetem nieobjętych za rok 1880 [w:] Alegata do sprawozdań stenograficznych z piatej sesyi czwartego perydu Sejmu Krajowego Królestwa Galicyi i Lodomeryi wraz z Wielkiem Ks. Krakowskiem z roku 1882, s. 22; Sprawozdanie Wydziału Krajowego o zamknięciu rachunków funduszów krajowych za rok 1881, Lit. B, Zamknięcie rachunku funduszów samoistnych (niedotowanych) budżetem nieobjętych za rok 1881 [w:] Alegata do tomu pierwszego sprawozdań stenograficznych z pierwszej sesyi piatego perydu Sejmu Krajowego Królestwa Galicyi i Lodomeryi wraz z Wielkiem Ks. Krakowskiem z roku 1883, s. 13; Sprawozdanie Wydzialu Krajowego o zamknięciu rachunków funduszów krajowych za rok 1883, Lit. B, Zamknięcie rachunku funduszów samoistnych (niedotowanych) budzetem nieobjętych za rok 1883, [w:] Alegata do sprawozdań stenograficznych z trzeciej sesyi piątego perydu Sejmu Krajowego Królestwa Galicyi i Lodomeryi wraz z Wielkiem Ks. Krakowskiem z roku 1885/6, s. 298; Sprawozdanie Wydziału Krajowego o zamknięciu rachunków funduszów krajowych za rok 1884, Lit. B, Zamknięcie rachunku funduszów samoistnych (niedotowanych) budzetem nieobjętych za rok 1884, [w:] Alegata do sprawozdań stenograficznych z trzeciej sesyi piatego perydu Sejmu Krajowego Królestwa Galicyi i Lodomeryi wraz z Wielkiem Ks. Krakowskiem z roku 1885/6, s. 324; Sprawozdanie Wydziału Krajowego o zamknięciu rachunków funduszów krajowych za rok 1885, Lit. B, Zamknięcie rachunku funduszów samoistnych (niedotowanych) budżetem nieobjętych za rok 1885 [w:] Alegata do sprawozdań stenograficznych z czwartej sesyi piatego perydu Sejmu Krajowego Królestwa Galicyi i Lodomeryi wraz z Wielkiem Ks. Krakowskiem z roku 1886/7, s. 358; Sprawozdanie Wydziału Krajowego o zamknięciu rachunków funduszów krajowych za rok 1886, Lit. B, Zamknięcie rachunku funduszów samoistnych (niedotowanych) budzetem nieobjętych za rok 1886 [w:] Alegata do sprawozdań stenograficznych z piątej sesyi piątego perydu Sejmu Krajowego Królestwa Galicyi i Lodomeryi wraz z Wielkiem Ks. Krakowskiem z roku 1887/8, s. 379; Sprawozdanie Wydziału Krajowego o zamknięciu rachunków funduszów krajowych za rok 1887, Lit. B, Zamknięcie rachunku funduszów samoistnych budżetem nieobjętych za rok 1887 [w:] Alegata do drugiego tomu sprawozdań stenograficznych z czwartej sesyi piatego perydu Sejmu Krajowego Królestwa Galicyi i Lodomeryi wraz z Wielkiem Księstwem Krakowskiem ze stycznia 1889 od 26-go do 40-go posiedzenia, s. 412.

43 Ibidem. 
udało się podnieść kwoty wypłacanych stypendiów do 300, 450 i 600 złotych reńskich rocznie. Po reformie walutowej stypendia wynosiły zaś odpowiednio do 600, 900 i 1200 koron rocznie ${ }^{44}$.

Z okresu II Rzeczpospolitej informacji dotyczących wydawanych stypendiów, ich wysokości, a także samych stypendystów jest jeszcze mniej. Wprawdzie $w$ Sprawozdaniach Politechniki Lwowskiej za lata akademickie 1919/1920-1930/1931 wspomniano o stypendiach nadawanych przez Tymczasowy Wydział Samorządowy, a następnie przez wojewodę lwowskiego, ale informacje te są ogólne i podawane łącznie dla wszystkich fundacji. Dopiero od roku akademickiego 1931/1932 w Sprawozdaniach zaczęto umieszczać szczegółowe informacje co do ilości i kwoty stypendiów wydawanych z poszczególnych instytucji i fundacji stypendialnych. Dzięki temu można obliczyć, że w latach akademickich 1931/1932-1939/1940 z Fundacji im. Antoniego Dydyńskiego tylko na samej Politechnice Lwowskiej wydano 58 stypendiów na łączną kwotę 32400 złotych, przy czym 31 stypendiów opiewało na kwotę 400 złotych, 19 na 800 złotych, a 8 - na 600 złotych rocznie ${ }^{45}$.

Również zachowane w Archiwum Uniwersytetu Jagiellońskiego dokumenty dostarczają sporo informacji dotyczących stypendystów fundacji kształcących się na tym uniwersytecie w latach 1919-1939. W aktach wydziałów, głównie Wydziału Filozoficznego i Wydziału Prawnego, znaleźć można wnioski o nadanie stypendium z Fundacji im. Antoniego Dydyńskiego kierowanych przez studentów do Tymczasowego Wydziału Samorządowego we Lwowie, a później do departamentu fundacyjnego przy wojewodzie lwowskim. Wśród dokumentów występują także odpisy decyzji o przyznaniu stypendium i kwocie, jaka miała zostać wypłacona stypendyście. Są to jednak dokumenty pojedyncze i pochodzące $\mathrm{z}$ różnych lat okresu międzywojennego, dlatego też nie można na ich podstawie określić dokładnej liczby stypendystów, którym fundacja udzieliła wsparcia w tym czasie ${ }^{46}$. Kwoty stypendiów, jakie otrzymywali, nie różniły się jednak od tych wypłacanych studentom Politechniki Lwowskiej i wynosiły 600 lub 800 złotych rocznie ${ }^{47}$.

44 Ibidem; Szematyzm... [za lata 1861-1914]; „Gazeta Lwowska” 1861-1914; ZNiO, sygn. 15687/ II., Fragment archiwum oo. Zmartwychwstańców we Lwowie. Papiery dotyczące Zakładu Wychowawczego oo. Zmartwychwstańców w latach 1882-1918, D. Pisma różne związane ze stypendiami dla wychowanków internatu, poz. 1, Papiery dotyczące stypendium fundacji Antoniego Dydyńskiego przyznanego Marianowi Ludwikowi Dydyńskiemu, uczniowi Szkoły Ludowej im. Konarskiego we Lwowie 1889, s. 309-316; Archiwum Uniwersytetu Jagiellońskiego (dalej: AUJ), sygn. WF II 96, Fundacje stypendialne pod zarządem Wydziału Krajowego sejmu we Lwowie potem wojewody lwowskiego, poz. 6, Stypendia Antoniego Dydyńskiego (1879-1934), b.n.; AUJ, sygn. WL II 118, Fundacje stypendialne pod zarządem Wydziału Krajowego sejmu Galicji, (potem wojewody lwowskiego) w latach 1855-1922, poz. 8, Stypendia Antoniego Dydyńskiego (1879-1915), b.n.; AUJ, sygn. WP II 117, Fundacje stypendialne pod zarządem Namiestnictwa i Wydziału Krajowego sejmu galicyjskiego (potem wojewody lwowskiego) w latach 1871-1922, poz. 9, Stypendia Antoniego Dydyńskiego (1882-1922), b.n.

45 Program Szkoły Politechnicznej we Lwowie na rok naukowy: 1919/20 i 1920/21, Lwów 1919-1920; Program Politechniki Lwowskiej na rok akademicki: 1921/22-1939/40, Lwów 1921-1939.

${ }_{46}$ AUJ, sygn. WF II 96, poz. 6; AUJ, sygn. WP II 117, poz. 9.

47 Ibidem. Wśród studentów UJ pobierających stypendium Fundacji im. Antoniego Dydyńskiego w latach 1918-1932 byli: Jan Rozwadowski, student Wydziału Rolniczego, Eugeniusz Seńkowski z Wy- 
Prócz otrzymywanych stypendiów stypendyści Fundacji im. Antoniego Dydyńskiego mogli liczyć na dodatkowe wsparcie finansowe z jej strony, które wypłacane było również przez cały okres jej działalności. Warto wspomnieć tutaj o dwóch studentach korzystających z nadzwyczajnego wsparcia w celu uzupełnienia swojej wiedzy na zagranicznych uczelniach. Pierwszą z nich był student wydziału filozoficznego UJ Michał Siedlecki ${ }^{48}$, brat malarza Franciszka ${ }^{49}$, studenta wydziału prawa UJ, który, nawiasem mówiąc, również pobierał stypendium z Fundacji im. Antoniego Dydyńskiego. W 1897 roku Michał Siedlecki otrzymał nadzwyczajne wsparcie w wysokości 600 złotych reńskich rocznie na kontynuację studiów w Collège de France, a następnie w Instytucie Pasteura w Paryżu ${ }^{50}$. Drugą osobą był uczeń ówczesnej Szkoły Politechnicznej we Lwowie Kazimierz Straszewski ${ }^{51}$, który w 1903 roku otrzymał 600 koron na kontynuację nauki w belgijskim Instytucie Elektrotechnicznym im. Montefiore w Liege ${ }^{52}$.

Zarysowana powyżej pokrótce historia Fundacji im. Antoniego Dydyńskiego stanowi porównanie pierwotnej woli fundatora z rzeczywistą sytuacją po uruchomieniu fundacji. Podjęty problem badawczy zasługuje w moim odczuciu na szersze opracowanie. Wiele zagadnień, w tym rozdawnictwo stypendiów, a także kwestie związane z gruntami fundacyjnymi i ich dzierżawą, wymaga dodatkowych kwerend i badań.

$* * *$

Odpis aktu ustanawiającego przez Antoniego Dydyńskiego fundację na rzecz ubogiej młodzieży przechowywany jest w Lwowskiej Naukowej Bibliotece NAN Ukrainy im. Wasyla Stefanyka, Oddział Rękopisów, w zespole (fond) 141, Zbiór Aleksandra Czołowskiego, w dziale (opis) II, pod sygnaturą 161, Papiery rodzinno-majątkowe Franciszka Dydyńskiego (1698-1836), na kartach 100-101. Jego wersja cyfrowa znajduje się w Zakładzie Narodowym im. Ossolińskich we Wrocławiu pod sygnaturą DE-6478, a także jest dostępna na stronie internetowej tej instytucji.

działu Filozoficznego, a także Wojciech Siedlecki, Janusz Kowalski i Kazimierz Rodowicz, wszyscy studiujący na Wydziale Prawnym.

48 Michał Siedlecki (1873-1940), zoolog i profesor UJ. Studiował zoologię na UJ (1891-1895), a następnie w Instytucje Zoologicznym w Berlinie (1895-1896) oraz Collège de France i Instytucie Pasteura w Paryżu. Po uzyskaniu profesury został kierownikiem Katedry Zoologii UJ, a w latach 19191921 był także rektorem Uniwersytetu Stefana Batorego w Wilnie.

49 Franciszek Siedlecki (1867-1934), malarz, grafik, autor scenografii teatralnych, krytyk sztuki i teatrolog reprezentujący nurt symbolizmu i secesji.

50 AUJ, sygn. WF II 96, poz. 6.

51 Kazimierz Straszewski (1879-1959), inżynier elektryk i inżynier mechanik, członek założyciel Stowarzyszenia Elektryków Polskich w 1919 r. i jego prezes w 1. 1928-1931 i 1946-1948. W 1908 r. został kierownikiem przedstawicielstwa firmy „Siemens-Schuckert” na Galicję, a po II wojnie światowej był jednym z twórców planu budowy ogólnokrajowego systemu energetycznego i kierował opracowaniem zarysu trzyletniego Planu Elektryfikacji Kraju.

52 Sprawozdanie z czynności komisji krajowej dla spraw przemystowych za czas od 1 stycznia 1903 do 30 czerwca 1904 [w:] Alegata do sprawozdań stenograficznych z drugiej sesyi ósmego perydu Sejmu Krajowego Królestwa Galicyi i Lodomeryi wraz z Wielkiem Księstwem Krakowskiem z roku 1904, s. 18. 
Poniżej zamieszczona została wersja łacińska aktu, a także jego tłumaczenie na język polski, z uwzględnieniem wskazówek zawartych w instrukcji wydawniczej dla źródeł z przełomu XIX i XX wieku ${ }^{53}$.

\section{Edycja dokumentu}

[k. 100v.] Institutum pauperae iuventutis

Cum lege civili cuilibet de re propria disponendi facultas data sit, hinc ego Antonius Dydyński in praesentia testium (quibus neque eorum successoribus subscriptiones hae nocere possunt) deficientibus heredibus ex lumbis meis procedentibus, neque existentibus successoribus ascendentibus, partem substantiae meae, videlicet bona hereditaria Godowa in Galicia Orientali situata, cum omnibus ad haecce bona spectantibus praedijs, agris, sylvis, pratis, subditis, eorumque praestationibus propinatione, molendinis, aedificijs curialibus et oeconomicis etc. nec non cum omni re mobili sub quocumque nomine et titulo, in fundo eorundem bonorum Godowa reperibili, nihil quidquam sibi de hisce bonis pro me aut pro meis successoribus excipiendo, meo successorumque meorum nomine, haecce praedita bona Godowa, numquam sub quocumque titulo alienanda aut oneranda, perpetuo et in aevum duraturo, et numquam cessaturo Instituto pauperae iuventutis expono - has Instituti regulas expresse adijciendo-

I. Ex nomine meo Dydynskiano continuo incessanter, et in perpetuum de tempore in tempus conformando se semper legibus in his regnis vigentibus et vegeturis de educatione Iuventutis sancitis et sancituris, proles in numero quattuor masculina educanda ipsique ex hoc fundo in toto prospiciendum.

II. In defectu iuventutis nominis mei iuventus Rosnowskiana ex nomine piae defunctae uxoris meae, et in defectu hujus iuventutis alterius nominis dummodo nobilis et ex legitimo matrimonio nata ad hocce Institutum suscipiatur.

III. Administrator hujus Instituti, per edicta publica, per ephemerides, aliasque literas, concursum ad vacantia hujus Instituti loca aperiat, insinuaturam se iuventutem ab annis 7. ad 15. annum aetatis suscipiat, in concursu candidatorum aspirantibus de nomine meo caeteris dabit praeferentiam, et ita continuo [k. 100r.] et incessanter progrediendum erit, ut destinatus numerus quattuor educandorum semper completus sit.

IV. Suscepta ad hocce Institutum iuventus vestibus honestis (absque tamen luxu) induatur, victu atque honesto nuntiatur- tempore a studiis vacante in bonis Godowa Instituto expositis recreetur, atque semel ad hocce Institutum suscepta iuventus non prius ex hocce Instituto dimittatur, quam

53 J. Tandecki, K. Kopiński, Edytorstwo źródet historycznych, Warszawa 2014. Przy tłumaczeniu tekstu z języka łacińskiego cennych rad udzieliła autorowi Pani Alina Paliwoda-Wielgos, za co składa on serdeczne podziękowania. 
quousque certum modum sustentandi, aut munus publicum vocationi ipsorum conforme adovisita non fuerit.

V. Iuvenes ad Insitutum suscepti de probitate morum et bono progressu in studijs attestatis sese coram Administratore omni medio anno producendis legitimabunt, hebetes et immorigeri admuneantur et corrigantur, incorrigibiles de hocce Instituto dimittantur, et pro semper beneficio hujus Instituti priventur, et vacans Instituti locus alio digniori suppleatur.

VI. Bona haecce mea Godowa cum attinentijs Instituto moderno in aeternum duraturo exposita, numquam cum quocumque titulo alienanda, per virum rectum et probum, ab Administratore moderno per me fundantem constituto, post sera ipsius vero fata proponendum, et per Iudicium Nobilium, cui iurisdictioni bona Godowa eotunc suberunt confirmandum administrentur.

VII. In concursu candidatorum pro Administratore candidati de nomine meo caeteris paribus prae alijs praecellentiam habebant.

VIII. Administrator hujus Instituti praeter pensionem annuam in quanto $8000 \mathrm{fp}$ ex proventibus boni Godowa percipiendam, insuper liberam mansionem in curia Godoviensi et libera ligna pro foco ex sylvis Godoviensibus percipiat.

IX. Administratoris officij erit bona haecce Godowa cum attinentijs huic Instituto exposita, uti virum rectum et honestum decet administrandi, quem in finem iuramentum fidelitatis coram iurisdictione iudicis nobilis praestabit. Proventus hosce qua bonus Pater familias omni honesto modo augere curabit, perceptos [k. 101v.] proventus colliget, ex his in educationem iuventutis ad hocce Institutum suscepta erogabit. Iuxta punctum II. hujusce Instituti sustentanda, atque detruncata sibi praevie assignata pensione, ex restantibus proventibus quotannis $1000 \mathrm{fp}$ pro bibliotheca sub titulo Antonio Dydynskiana erigenda impendet, licitos libros auctorum excellentiorum coemet, quos Instituto utiles administrator videbit, quive libri quotannis coemendi, juxta ordinatam indicem consignandi, huic perpetuo Instituto incorporandi, quem in finem in palatio Godoviensi in insuper proventus alterius a contributionibus publicis, a reparatione aedificiorum, a sustentandis officialibus, et meliorando fundo instructo superrestantes Administrator colligat, secure deponat, et ex his collectis adolescentibus ex hoc Instituto finita educatione exeuntibus, pro rerum circumstantia succurrat.

X. Nihilominus tamen licet Administratorum hujus Instituti nomine Tutoris et Curatoris confisae ipsi iuventutis authorisare voto, attamen licet primus per me constitutus Administrator Magnificus Dominus Raphael de Ostoja Niedzwiecki a dando calculo cuipiam tertio liber sit, non ita de subsequis Instituti Administratoribus inteligendum, qui rationes de praeceptis et erogatis proventibus quotannis Foro Nobilium (cui bona Godowa suberunt) dare sub poena anuntionis ab officio tenebuntur. Quive jurisdictioni Fori Nobilium subordinati erunt et omni anno de statu Instituti, de moralitate et progressu iuventutis huic praepositae sibi instantiae regere non intermittent, et legibus eatenus sancitis in toto obtemperabunt, ac denique. 
XI. Institutum hoc ita fundatum non citius inhoabitur, prius quam pactum me inter et MD Raphaelem de Ostoja Niedzwiecki stipulatum non cessaverit, et quousque idem Administrator Magnificus Raphael de Ostoja Niedzwiecki ad idem Institutum aperiendum tempus non definiverit, [k. 101r.] quod ita factum Institutum pauperae iuventutis perpetuo duraturum manu propria cum amicis qua testibus (absque eorum noxas) subscribo, sigillumque appono et super bonis meis hereditarijs Godowa in tabulam permitto.

Datum in Godowa 2 II 1808 anno.

Antonius Dydyński bonorum Godowa cum attinentibus heres m.p.L.S. (-).

Accepto administrationem Raphael v Ostoja Niedzwiecki primus Instituti Administrator m.p.L.S. (-).

Qua praesens hujus Instituti testis subsigno. Franciscus Xaver comes de Jabłonowski Canonicus Vladislaviensis m.p.L.S. (-).

Qua praesens hujus Instituti testis subsigno. Antonius Łempicki m.p.L.S. (-).

Qua praesens hujus Instituti testis subscribo. Vincentius Oraczewski m.p.L.S. (-).

Qua praesens hujus Instituti testis subsigno. Sebastianus Brochwicz Rogoyski Canonicus Cathedralis Vladislaviensis et Praepositus Strzyszoviensis m.p.L.S. (-).

\section{Tłumaczenie na język polski}

Fundacja Ubogiej Młodzieży

Skoro na mocy prawa cywilnego każdemu dana została możność dysponowania jego majątkiem, stąd ja, Antoni Dydyński, w obecności świadków (którym, jak i których sukcesorom, niniejsze zapisy nie mogą zaszkodzić), wobec braku spadkobierców po mieczu, jak i spadkobierców w linii wstępnej, część mego majątku, mianowicie dobra dziedziczne Godowa, położone we wschodniej Galicji, ze wszystkimi do tych dóbr przypisanymi pożytkami, polami, łąkami, lasami i świadczeniami z nich, wraz z szynkiem, młynami, budynkami dworskimi i gospodarczymi, jak też z wszelkim majątkiem ruchomym, znajdującym się z jakiegokolwiek tytułu na terenie rzeczonych dóbr Godowa, w całości, jako majątek nigdy niesprzedany i nieobciążony na czyjąkolwiek korzyść, nie zastrzegając sobie z niego nic dla siebie ani dla swoich spadkobierców, przekazuję na zawsze, w trwałe i nieprzerwane posiadanie Fundacji Ubogiej Młodzieży, załączywszy te oto reguły Fundacji:

I. $\quad Z$ całości tego funduszu należy kształcić młodzież męską, w ilości 4 osób, pochodzącą z mojego rodu Dydyńskich, co czynić należy corocznie, ciągle i nieprzerwanie, zgodnie z obowiązującymi w królestwie prawami w zakresie edukacji, zarówno aktualnymi, jak też tymi, które zostaną w przyszłości uchwalone.

II. W przypadku braku młodzieży z mojego rodu należy wybierać do tej Fundacji młodzież z rodu Rosnowskich, czyli z rodu mojej świętej pamięci 
małżonki, a w razie braku i tejże młodzieży, z innego rodu szlacheckiego, pochodzącą z prawego łoża.

III. Zarządca tej Fundacji niechaj przeprowadza konkurs na wakujące do niej miejsca poprzez publiczne ogłoszenia, rejestry i inne pisma; niech przyjmuje zamierzającą doń przystąpić młodzież w wieku od 7 do 15 lat, przedkładając kandydatów o moim nazwisku nad innych. Czynić tak ma ciągle i nieprzerwanie, iżby zawsze wypełniona była liczba 4 wychowanków.

IV. Przyjęta do Fundacji młodzież powinna być odziana w godną odzież, jednak bez luksusu, i winna korzystać z godnego wiktu. W czasie wolnym od nauki niechaj zażywa odpoczynku w dobrach Godowa, oddanych na rzecz Fundacji. Niechaj też raz przyjęta do tejże Fundacji młodzież nie wcześniej z niej zostanie odesłana, zanim zdobędzie jakiś sposób utrzymania albo osiągnie zdolność do sprawowania służby publicznej.

V. Młodzieńcy przyjęci do Fundacji corocznie w trakcie pobierania nauki mają się legitymować co do swej prawości obyczajowej i postępów w nauce poprzez przynoszone zarządcy świadectwa. Gnuśni i niezdyscyplinowani powinni zostać napomniani i się poprawić. Niepoprawni zaś powinni zostać usunięci z Fundacji i na zawsze zostać pozbawieni jej dobrodziejstw, a wakujące po nich miejsce powinno zostać przeznaczone dla innych, godniejszych młodzieńców.

VI. Moje zaś dobra Godowa, wraz z przyległościami, przekazane na wieczne użytkowanie nowej Fundacji, nie powinny być nigdy z jakiejkolwiek przyczyny sprzedane, ale winny być zarządzane przez męża prawego i sprawiedliwego, którego na następcę zaproponować ma zarządca ustanowiony właśnie przeze mnie jako fundatora, a zatwierdzić powinien sąd szlachecki, pod jurysdykcję którego majątek Godowa będzie wtedy podlegał.

VII. W konkursie kandydatów na zarządcę, w sytuacji gdy szanse są wyrównane, niechaj kandydaci z mojego rodu mają przewagę nad innymi.

VIII. Zarządca tej Fundacji, oprócz rocznej pensji w wysokości 8000 florenów, wypłacanej z dochodów majątku Godowa, ma otrzymać ponadto darmowe mieszkanie we dworze w Godowej i drewno na opał z lasów godowskich.

IX. Obowiązkiem zarządcy będzie tak dysponować przekazanym Fundacji majątkiem Godowa wraz z przyległościami, jak to przystoi mężowi prawemu i sprawiedliwemu, na dowód czego złoży przysięgę w obliczu sędziego wedle stosownej jurysdykcji. Będzie się starał powiększać dochód wszelkimi uczciwymi sposobami, gromadzić zyski niczym dobry ojciec rodziny, z nich zaś będzie łożył na edukację i utrzymanie młodzieży przyjętej do Fundacji (stosownie do punktu II regulaminu tej Fundacji), a po wypłaceniu sobie pensji z pozostałych dochodów będzie przeznaczał 1000 florenów polskich na utworzenie Biblioteki imienia Antoniego Dydyńskiego. Będzie kupował stosowne książki znakomitych autorów, które jako zarządca uzna za przydatne dla Fundacji. Książki te, dokupowane corocznie, wpisywane systematycznie do katalogu, na zawsze mają wejść w skład 
majątku Fundacji, a na ten cel ma zostać przeznaczona większa komnata na piętrze w pałacu w Godowej.

X. Zyski pozostałe po opłaceniu podatków, przeprowadzeniu remontów budynków, opłaceniu utrzymania służby i dokonaniu melioracji gruntów zarządca ma gromadzić, bezpiecznie deponować i z tych zasobów wspierać młodzieńców odchodzących z Fundacji po zakończeniu nauki, a będących w trudnym położeniu.

XI. Ponadto wypada, żeby zarządca tej Fundacji, z tytułem Opiekuna i Kuratora, był zatwierdzany poprzez uwierzytelnione głosowanie młodzieży, przy czym pierwszy ustanowiony przeze mnie zarządca, wielmożny pan Rafał de Ostoja Niedźwiecki winien być zwolniony od przedstawiania sprawozdania komukolwiek trzeciemu. Inaczej należy myśleć o kolejnych zarządcach Fundacji, którzy będą zobowiązani z przychodów i wydatków zdawać corocznie sprawozdanie przed sądem szlacheckim, któremu majątek Godowa będzie podlegał, pod groźbą odsunięcia od obowiązków. Będą oni podlegać jurysdykcji sądu szlacheckiego, cały rok nieprzerwanie będą dbać o stan Fundacji, o postępy młodzieży i obyczaje w tej powierzonej sobie instytucji i będą posłuszni w tym zakresie uchwalonym prawom.

XII. Fundacja w ten sposób utworzona nie wcześniej zostanie zamieszkana, zanim zostanie zatwierdzona umowa między mną a wielmożnym panem Rafałem de Ostoja Niedźwieckim i zanim tenże jako zarządca nie wyznaczy terminu otwarcia Fundacji. Aby tak utworzona Fundacja Ubogiej Młodzieży istniała nieustannie, niniejszy dokument własnoręcznie podpisuję, mając za świadków przyjaciół (bez przymusu z ich strony), pieczętuję pieczęcią i przesyłam do rejestru moich dóbr dziedzicznych Godowa.

Dano w Godowej, 2 lutego 1808r.

Antoni Dydyński, dziedzic majątku Godowa (-).

Przyjmuję zarząd - Rafał de Ostoja Niedźwiecki, pierwszy zarządca fundacji (-). Jako świadek tej fundacji podpisuje Franciszek Ksawery hrabia de Jabłonowski, kujawski kanonik katedralny (-).

Jako świadek podpisuje Antoni Łempicki (-).

Jako świadek podpisuje Wincenty Oraczewski (-).

Jako świadek fundacji podpisuje Sebastian Brochwicz Rogoyski (-). 


\section{BIBLIOGRAFIA}

\section{Źródła archiwalne}

Archiwum Narodowe w Krakowie

zesp. 684, Teki Antoniego Schneidra, sygn. 462.

Archiwum Państwowe w Przemyślu

zesp. 65, Sąd Powiatowy w Strzyżowie, sygn. 72(132)/2005, Fundacja Stypendialna śp. Antoniego Dydyńskiego przeciw Stanisławowi Dydyńskiemu i wspólnikom o oddanie przedmiotu dzierżawy (1921-1923), 121 ss.; sygn. 89(132)/2005, Fundacja Stypendialna im. Antoniego Dydyńskiego przeciw Jakubowi Szczygłowi o ustąpienie z posiadania (1928 [1929]), 23 ss.; sygn. 120(132)/2005, Fundacja Stypendialna im. Antoniego Dydyńskiego przeciw Janowi Zamorskiemu o naruszanie w posiadaniu gruntu (1928 [1929]), 24 ss.; sygn. 90(132)/2005, Fundacja Stypendialna im. Antoniego Dydyńskiego przeciw Stanisławowi Moskalowi o ustąpienie z posiadania (1926-1928 [1929]), 43 ss.

gr. zesp. Akta notariuszy miasta Strzyżowa z lat 1873-1947:

zesp. 102, C.K. notariusz Konstanty Rogalski w Strzyżowie, sygn. 2, nr 319, Protokół odbioru przez Józefa Etgensa akt urzędowych dotyczących fundacji edukacyjnej śp. Antoniego Dydyńskiego (31 XII 1874).

zesp. 1246, Akta c.k. notariusza Feliksa Miskyego w Strzyżowie, sygn. 3, nr 502, Legalizacja podpisu na kontrakcie najmu z dnia 30 X 1880 r., mocą którego Apolinary Dydyński działając w imieniu dóbr funduszowych Godowa, wypuszcza w najem Towarzystwu Zaliczkowemu i Kredytowemu w Strzyżowie pomieszczenia w budynku z realności w Strzyżowie położonej i do fundacji tej należącej (2 XI 1880); sygn. 5, nr 675, Kontrakt dzierżawy dóbr Godowa sekcji I należących do fundacji stypendialnej śp. Antoniego Dydyńskiego, zawarty pomiędzy, działającym w imieniu fundacji, Janem Stanisławem Ignacym Skrzyńskim właścicielem dóbr Strzyżowa z przyległościami i kuratorem tejże fundacji, a Adolfem Kernem dotychczasowym dzierżawcą folwarku Godowy sekcji I (30 V 1881); sygn. 5, nr 676, Kontrakt dzierżawy dóbr Godowa sekcji II należących do fundacji stypendialnej śp. Antoniego Dydyńskiego, zawarty pomiędzy, działającym w imieniu fundacji, Janem Stanisławem Ignacym Skrzyńskim właścicielem dóbr Strzyżowa z przyległościami i kuratorem tejże fundacji, a Karolem Krasińskim dotychczasowym dzierżawcą folwarku Godowy sekcji II (30 V1881).

zesp. 1248, Notariusz Adam Bański w Strzyżowie, sygn. 18, nr 3521, Kontrakt dzierżawy folwarku Godowa zawarty z Stanisławem Filipowiczem (2 X 1929).

Archiwum Państwowe w Rzeszowie

zesp. 308, Powiatowy Pełnomocnik dla spraw Reformy Rolnej w Rzeszowie, sygn. 37, Administracja przejściowa majątku w Godowej. Sprawozdania i korespondencja (1944); k. 5.

zesp. 152, Wojewódzki Urząd Ziemski w Rzeszowie, sygn. 824, Parcelacja majątków: Mrow-

la, Słocina, Chmielnik, Kosina, Werynia, Kolbuszowa, Załęże, Rogóżno, Wola Mała, Łańcut, Łańcut „Górne”, Błażowa, Godowa (1944).

zesp. 519, Archiwum Lubomirskich, sygn. 22, Kontrakty dzierżawy wsi i miast (1665, 1771).

Archiwum Uniwersytetu Jagiellońskiego

sygn. WF II 96, Fundacje stypendialne pod zarządem Wydziału Krajowego sejmu we Lwowie potem wojewody lwowskiego, poz. 6, Stypendia Antoniego Dydyńskiego (1879-1934), b.n. 
sygn. WL II 118, Fundacje stypendialne pod zarządem Wydziału Krajowego sejmu Galicji (potem wojewody lwowskiego) w latach 1855-1922, poz. 8, Stypendia Antoniego Dydyńskiego (1879-1915), b.n.

sygn. WP II 117, Fundacje stypendialne pod zarządem Namiestnictwa i Wydziału Krajowego sejmu galicyjskiego (potem wojewody lwowskiego) w latach 1871-1922, poz. 9, Stypendia Antoniego Dydyńskiego (1882-1922), b.n.

Lwowska Naukowa Biblioteka Ukrainy im. W. Stefanyka

zesp. (fond) 141, Zbiór Aleksandra Czołowskiego, dział (opis) II, sygn. 161, Papiery rodzinno-majątkowe Franciszka Dydyńskiego (1698-1836).

Zakład Narodowy im. Ossolińskich we Wrocławiu

sygn. 15711/III, „Rodowody”. Tablice genealogiczne i materiały do nich dotyczące rodzin spokrewnionych z Jaszczurowskimi. Zebrał i zestawił Tadeusz Alojzy Jaszczurowski, Lit. Dy-J, poz. I. Dydyńscy v. Dedyńscy v. Didińscy h. Gozdawa: 1. Tablice genealogiczne.

akc. 200/82, Papiery rodzin Dydyńskich i Żuk-Skarszewskich: Tablice Genologiczne.

sygn. 12329/II, Księga spraw majątkowych księżny Joanny de Stein Lubomirskiej, chorążyny wielkiej koronnej z lat 1755-1761, poz. 10, Copia kontraktu z WJM panem Michałem Dydyńskim, chorążym zakroczymskim, o dobra godowskie. Anno 1755, s. 63-66, poz. 41, Copia kwitu na z. 700 vigore prorogacyi kontraktu z dóbr godowskich od WW Jchm PP Dydyńskich pro die 24 Marc 1760 Anno należących y odebranych, s. 350 .

sygn. 15687/II., Fragment archiwum oo. Zmartwychwstańców we Lwowie. Papiery dotyczące Zakładu Wychowawczego oo. Zmartwychwstańców w latach 1882-1918, D. Pisma różne związane ze stypendiami dla wychowanków internatu, poz. 1, Papiery dotyczące stypendium fundacji Antoniego Dydyńskiego przyznanego Marianowi Ludwikowi Dydyńskiemu, uczniowi Szkoły Ludowej im. Konarskiego we Lwowie 1889, s. 309-316.

\section{Źródła drukowane}

Boniecki A., Herbarz Polski, cz. 1: Wiadomości historyczno-genealogiczne o rodach szlacheckich, t. 5, Warszawa 1902.

Działalność władz okupacyjnych na terytorium Rzeczypospolitej wokresie 1 IX 1939-1 XI 1940. Raport z archiwum politycznego prof. Stanistawa Kota, wstęp, wybór i oprac. J. Gmitruk, J. Mazurek, Warszawa 1999.

Łodzia Czarniecki K., Herbarz polski podtug Niesieckiego, treściwie ułożony i wypisami z późniejszych autorów, z różnych akt grodzkich i ziemskich, z ksiag $i$ akt kościelnych oraz z dokumentów familijnych powiększony $i$ wydany, t. 1, Gniezno 1875-1881.

Pamiętnik Mariana Dydyńskiego z Raciborska (1843-1920), wyd. K. Gołąb-Malowicka, Kraków 2015.

Poczet szlachty galicyjskiej i bukowińskiej, Lwów 1857.

Program Politechniki Lwowskiej na rok akademicki: 1921/22-1939/40, Lwów 1921-1939.

Program Szkoły Politechnicznej we Lwowie na rok naukowy: 1919/20 i 1920/21, Lwów 19191920.

Sprawozdanie Wydziału Krajowego o zamknięciu rachunków funduszów krajowych za rok 1875,

Lit. C, Zamknięcie rachunku funduszów samoistnych (niedotowanych) budżetem nieobjętych za rok 1875 [w:] Alegata do sprawozdań stenograficznych z pierwszej sesyi czwartego pe- 
rydu Sejmu Krajowego Królestwa Galicyi i Lodomeryi wraz z Wielkiem Ks. Krakowskiem z roku 1877.

Sprawozdanie Wydziału Krajowego o zamknięciu rachunków funduszów krajowych za rok 1877,

Lit. B, Zamknięcie rachunku funduszów samoistnych (niedotowanych) budżetem nieobjętych za rok 1875 [w:] Alegata do sprawozdań stenograficznych z trzeciej sesyi czwartego perydu Sejmu Krajowego Królestwa Galicyi i Lodomeryi wraz z Wielkiem Ks. Krakowskiem z roku 1880.

Sprawozdanie Wydziału Krajowego o zamknięciu rachunków funduszów krajowych za rok 1879,

Lit. B, Zamknięcie rachunku funduszów samoistnych (niedotowanych) budżetem nieobjętych za rok 1879 [w:] Alegata do sprawozdań stenograficznych z czwartej sesyi czwartego perydu Sejmu Krajowego Królestwa Galicyi i Lodomeryi wraz z Wielkiem Ks. Krakowskiem z roku 1881.

Sprawozdanie Wydziału Krajowego o zamknięciu rachunków funduszów krajowych za rok 1880,

Lit. B, Zamknięcie rachunku funduszów samoistnych (niedotowanych) budżetem nieobjętych za rok 1880 [w:] Alegata do sprawozdań stenograficznych z piatej sesyi czwartego perydu Sejmu Krajowego Królestwa Galicyi i Lodomeryi wraz z Wielkiem Ks. Krakowskiem z roku 1882.

Sprawozdanie Wydziału Krajowego o zamknięciu rachunków funduszów krajowych za rok 1881,

Lit. B, Zamknięcie rachunku funduszów samoistnych (niedotowanych) budżetem nieobjętych za rok 1881 [w:] Alegata do tomu pierwszego sprawozdań stenograficznych z pierwszej sesyi piątego perydu Sejmu Krajowego Królestwa Galicyi i Lodomeryi wraz z Wielkiem Ks. Krakowskiem z roku 1883.

Sprawozdanie Wydziału Krajowego o zamknięciu rachunków funduszów krajowych za rok 1883, Lit. B, Zamknięcie rachunku funduszów samoistnych (niedotowanych) budżetem nieobjętych za rok 1883 [w:] Alegata do sprawozdań stenograficznych z trzeciej sesyi piatego perydu Sejmu Krajowego Królestwa Galicyi i Lodomeryi wraz z Wielkiem Ks. Krakowskiem z roku 1885/6.

Sprawozdanie Wydziału Krajowego o zamknięciu rachunków funduszów krajowych za rok 1884,

Lit. B, Zamknięcie rachunku funduszów samoistnych (niedotowanych) budżetem nieobjętych za rok 1884 [w:] Alegata do sprawozdań stenograficznych z trzeciej sesyi piatego perydu Sejmu Krajowego Królestwa Galicyi i Lodomeryi wraz z Wielkiem Ks. Krakowskiem z roku $1885 / 6$.

Sprawozdanie Wydziału Krajowego o zamknięciu rachunków funduszów krajowych za rok 1885,

Lit. B, Zamknięcie rachunku funduszów samoistnych (niedotowanych) budżetem nieobjętych za rok 1885 [w:] Alegata do sprawozdań stenograficznych z czwartej sesyi piatego perydu Sejmu Krajowego Królestwa Galicyi i Lodomeryi wraz z Wielkiem Ks. Krakowskiem z roku 1886/7.

Sprawozdanie Wydziału Krajowego o zamknięciu rachunków funduszów krajowych za rok 1886,

Lit. B, Zamknięcie rachunku funduszów samoistnych (niedotowanych) budżetem nieobjętych za rok 1886 [w:] Alegata do sprawozdań stenograficznych z piatej sesyi piatego perydu Sejmu Krajowego Królestwa Galicyi i Lodomeryi wraz z Wielkiem Ks. Krakowskiem z roku 1887/8.

Sprawozdanie Wydziału Krajowego o zamknięciu rachunków funduszów krajowych za rok 1887, Lit. B, Zamknięcie rachunku funduszów samoistnych budżetem nieobjętych za rok 1887 [w:] Alegata do drugiego tomu sprawozdań stenograficznych z czwartej sesyi piatego perydu Sejmu Krajowego Królestwa Galicyi i Lodomeryi wraz z Wielkiem Księstwem Krakowskiem ze stycznia 1889 od 26-go do 40-go posiedzenia.

Sprawozdanie z czynności komisji krajowej dla spraw przemysłowych za czas od 1 stycznia 1903 do 30 czerwca 1904 [w:] Alegata do sprawozdań stenograficznych z drugiej se- 
syi ósmego perydu Sejmu Krajowego Królestwa Galicyi i Lodomeryi wraz z Wielkiem Księstwem Krakowskiem z roku 1904.

Sprawozdanie z czynności Tymczasowego Wydziału Samorządowego we Lwowie za czas od 20 czerwca 1920 r. do 31 grudnia 1922, Lwów 1924.

Sprawozdanie z czynności Tymczasowego Wydziału Samorządowego we Lwowie za czas od 1 stycznia 1923 r. do 31 grudnia 1924 r. Lwów 1926.

Sprawozdanie z czynności Tymczasowego Wydziału Samorządowego we Lwowie za rok 1926, Lwów 1927.

Sprawozdanie z czynności Wydziału Krajowego za czas od 1 lipca 1884 do końca czerwca 1885 roku z alegatami 1-52 i indeksem [w:] Alegata do sprawozdań stenograficznych z trzeciej sesyi piątego perydu Sejmu Krajowego Królestwa Galicyi i Lodomeryi wraz z Wielkiem Ks. Krakowskiem z roku 1885/6.

Szematyzm Królestwa Galicyi i Lodomeryi z Wielkiem Księstwem Krakowskiem [za lata 18611914], Lwów 1861-1914.

\section{Opracowania}

Bąbiak G.P., Sobie, ojczyźnie czy potomności... Wybrane problemy mecenatu kulturalnego elit na ziemiach polskich w XIX wieku, Warszawa 2010.

Bieda T., Pierwsze lata niepodległości w regionie strzyżowskim 1944-1947 [w:] Studia nad dziejami Strzyżowa i okolic, red. S. Cynarski, Rzeszów 1980, s. 295-312.

Dybiec J., Finansowanie nauki i oświaty w Galicji 1860-1918, Kraków 1979.

Dybiec J., Mecenat naukowy i oświatowy w Galicji 1860-1918, Wrocław 1981.

Małecki M., Wydział krajowy sejmu galicyjskiego. Geneza, struktura i zakres kompetencji, nastęstwo prawne, Kraków 2014.

Ślusarek K., W przededniu autonomii. Własność ziemska i ziemiaństwo zachodniej Galicji w połowie XIX wieku, Warszawa 2013.

Tandecki J., Kopiński K., Edytorstwo źródet historycznych, Warszawa 2014.

\section{Prasa}

„Czas” 1862, nr 138.

„Gazeta Lwowska” 1861-1914. 